\title{
DE ÆLDSTE DANSKE ILLUMINERBØGER OG DERES KILDER
}

AF

\author{
Ove K. Nordstrand
}

\begin{abstract}
$\mathrm{D}$ e i de senere år så udbredte større og mindre håndbøger for fingernemme amatører med anvisninger for udførelsen af forskellige håndvarksbetonede fritidsarbejder er ikke, som man umiddelbart kunne fristes til at tro, nogen moderne foreteelse. Tvartimod kendes publikationer af denne art langt tilbage i tiden. Flertallet af de gamle hobbybøger har nu nappe større interesse uden for snævre fagkredse. Enkelte synes dog, enten ud fra indholdets særlige karakter eller på grund af specielle omstandigheder ved teksternes affattelse eller udgivelse, at være nøjere undersøgelser værd. Dette galder således de gamle receptbøger, som helt op til den nyestc tid har spillet en betydelig rolle ved at afgive det nødvendige grundlag for den husholdningsmæssige fremstilling af en række højst forskelligartede produkter af kemisk-teknisk karakter, såsom essenser, stoffarver, kosmetiske præparater, skosvarte etc. En del af receptbøgerne indeholder kun recepter med relation til eet bestemt område. Et eksempel herpå er illuminerbøgerne.

Illuminerbøgerne forekommer i ganske betydeligt tal i det 16.0 I 7 . århundredes litteratur, og behandler med middelalderlige bogmalertraditioner som baggrund mere eller mindre indgående tilvirkningen og anvendelsen af malerfarver etc.

Den tidligste danske illuminerbog, som kendes, stammer fra det 16 . århundredes sidste fjerdedel. Den er trykt af københavnerbogtrykkeren Lorentz Benedicht og bærer titlen: „Mange haande Artige Kaanster at berede gaat Blick oc alle haande Farffue, Oc at schriffue met Guld, Sølff oc alle Metal aff Feyre: Met mange andre nyttige Kaanster, at farffue schriffue feyre, oc Pergament, met alle haande Farffue. Oc huor mand skal lade Schrifft ædzis paa Staal eller Jern oc Vaaben. Alle Schriffuere, Breffmalere, Kniffuesmeder, oc andre som slig Kaanster bruge, gantske nyttige at vide."
\end{abstract}




\section{ssiange gaande

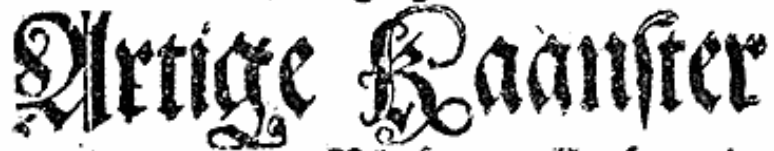 \\ at Gercoe gaat $\mathfrak{B}$ lict. of alle Shanbe} Jarfiue/ De at fohriffue met Buto/ Eolf of

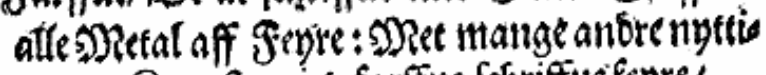
ge Raanfer/ at farffuc ferriffice fepre/ oc Dergament /met alle hraan os

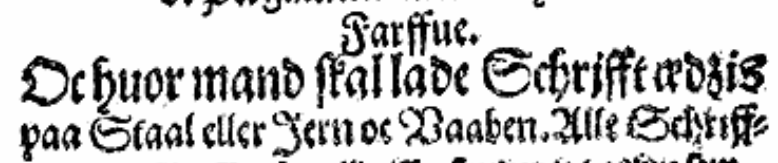

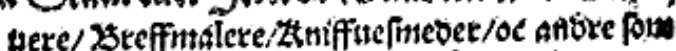
flig zanan|ter bruge/ganthe nyttige at vioe.

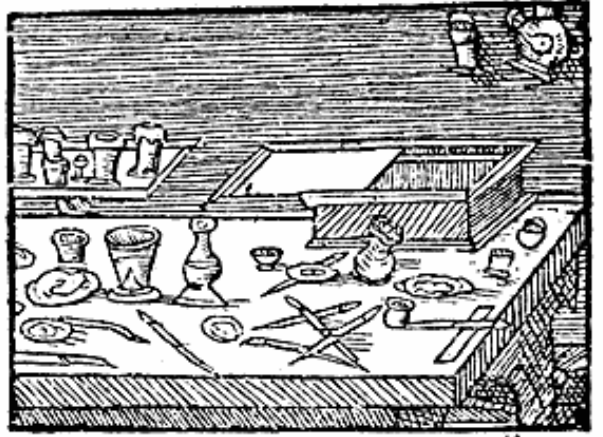

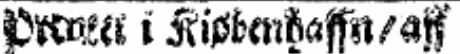
Sautentis Bencoirfie. Oc findis bofr batnem til eíbbo.

Lorentz Benedichts illuminerbog (efter ${ }_{1578}$ ). Linie 2, 3, 4, 9, 10 og 14 trykt med rod farve. Originalens storrelse.

i denne serie udkom samme år to illuminerbøger, $\mathrm{i}$ begge tilfalde oversættelser efter udenlandske forlæg og begge trykt af københavnerbogtrykkeren Peter Hake. Den første af disse, der fremkom som nr. 2 i serien, bærer titlen: „En liden dog konsterjg Bog Om adskillige slags Farffve oc Bleck. Huorledis mand skal farffve Træ, Been, Jern, Tin, Glas, Byrster, Klæde, Silcke, Skind oc Ledder, saa om atskillige slags Farffve at berede, at skriffve oc male med. Alle Skriffvere, Malere, Billedhuggere, 
Indleggere, Snedickere, Beendreyere, Fellberedere, Farffvere, Skomagere oc andre som til saadant Lyst haffver til Tieniste. Paa Tydske Tungemaal først sammenskreffven aff den vjtberømte, velforfarne Mand Alcxio Pedemontano. Oc nu meenige Mand til beste oc Tieniste paa vort Danske Sprog transferéret, udsat oc til Trycken forfærdiget. “ Bogen omfatter 34 blade (kolumnestørrelse $153 \times 9$ I $\mathrm{mm}$ ) og indeholder ialt 122 recepter.

Den originale tekst udkom første gang i Venedig 1555 under titlen „Secreti del Rev. Donno Alessio Piemontese.“ I I 559 udsendtes i Bascl en latinsk oversættelse foretaget af Joh. Jac.Wecker. Han havde ligeledes foretaget en tysk oversættelse, som udkom samme sted 1570 . Den italienske originaludgave var opdelt i 7 ,libri“, som hver bragte recepter med relation til eet bestemt felt, f. eks. medicin, kogekunst, maleri o. lign. Afsnittet med farverecepter afsluttede samlingen.

I de tyske Alessio-udgaver fra århundredets slutning deltes teksten i to dele, som hver for sig udsendtes som selvstændige bøger betegnet henholdsvis „Artzney-Buch“ og „Kunst-Buch“9). Disse udgaver har dannet grundlag for senere oversattelser til andre europæiske sprog, heriblandt dansk.

Om udgivelsen af Alessios Secreti hedder det et sted ${ }^{10}$ ), at han, der var en meget anset læge, havde samlet sine recepter gennem 57 års vidtstrakte rejser gennem Europa. Han betragtede oprindelig sine recepter som personlige hemmeligheder, men lod sig $\mathrm{i}$ en alder af $8_{3}$ år tilskynde til at udgive dem. Farvereceptsamlingen bærer ved sin usystematiske rækkefølge i høj grad præg af at være et kompilationsarbejde.

En gennemgang af den danske Alessio-udgave 1648 afslører i bogens sidste halvdel en ejendommelighed. Recepterne $\mathrm{i}$ bogens forste halvdel fremtræder i ganske vilkårlig orden, hvorfor det virker overraskende fra nr. 65 (p. 38) og bogen ud at finde dem ordnede i bestemt afgrænsede grupper på lignende måde som vi har set det i Benedichts illuminerbog. En sammenligning viser, at Alessioudgavens ordnede del må være et optryk af den fra Benedicht- og 1633-trykket kendte tekst, og at det nærmere betegnet må være sidstnæunte, som her er optrykt, idet samtlige afsnittets 54 recepter genfindes i dette tryk.

Den fjerde og sidste af illuminerbøgerne, der skal omtales her, udkom som nr. 3 i Oeconomia Nova-serien under titlen: „En Ny oc Konstrjg Illuminer-Bog Det er: Hvorledis konsteligen er at giøre oc berede alleslags Farffver, som er meget lystig oc gaffnlig at vide for Skriffverc, Malere oc andre som elske saadan Konst, sampt nogle nye tilsatte Konst-stycker, som tilforne aldrig cre udgangne paa Prent. Ved Valentinum Bolten aff Rufach. Oc nu paa Danske udsat, oc til Trycken forfardiget.“ 
Boltz' „Illuminierbuch“ udkom første gang i Basel I549. Boltz fungerede på daværende tidspunkt som reformert hospitalspræst i Basel. Ifølge en samtidig kilde" ) var embedet imidlertid så slet aflønnet, at han, udover at varetage sin præstegerning, var tvunget til at arbejde som maler. Dette antyder, at han må have gennemgået en vis oplæring i malekunsten. Da hans ungdom fortaber sig i mørke, kan stedet og tidspunktet for denne oplæring ikke fastslås. Det må dog i denne forbindelse bemærkes, at han stammede fra byen Rufach i provinsen Oberelsass, en egn hvor de middelalderlige bogmalertraditioner endnu op gennem det 15 . århundrede var levende ${ }^{12}$ ).

I indledningen til sin udgave af Boltz' „Illuminierbuch “ anfører Benziger ${ }^{13}$ ), at bogen ialt er udkommet i 16 udgaver, men desuden viser det sig, at Boltz' tekst i en rakke tilfæxlde i det 17. og 18 . århundrede i mere eller mindre maskeret form er optaget $\mathrm{i}$ andre forfatteres værker. Et typisk eksempel herpå er den af J.B. Pictorius i Nürnberg udgivne „IlluminirKunst" fra 1613 , hvor ikke alene Boltz' receptmateriale er opsuget i bogens øvrige tekst, men hvor endog visse clementer fra hans forord er optaget ordret i Pictorius' forord.

Den danske udgave af Boltz' Illuminierbuch 1648 omfatter 50 blade (kolumnestørrelse ${ }_{15} \mathrm{I} \times 9 \mathrm{I} \mathrm{mm}$ ) og er delvis fejlpagineret ${ }^{14}$ ). Den indeholder ialt $2 \mathrm{I} 7$ recepter, som $\mathrm{i}$ hovedtrak fordeler sig på følgende måde ${ }^{15}$ ):
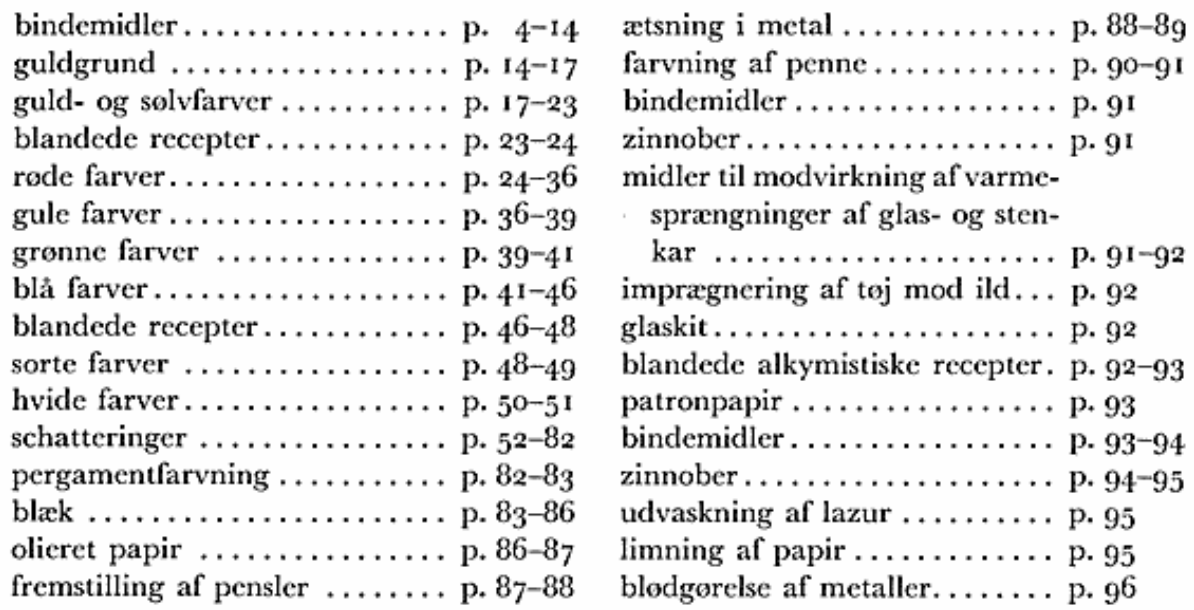

Sammenholder man denne oversigt med den tidligere gengivne oversigt over Benedichts illuminerbog bemærkes en udpraget lighed med hensyn til stoffets disposition. Men ligheden rakker videre. En gennemgang af hele receptmaterialet viser, at 18 recepter hos Benedicht ordret gen- 
rakkefølgen, hvori de forekommer, er næsten den samme. Der er derfor næppe tvivl om, at vi her står over for Benedichts og Boltz' falles kilde.

Vi kan på grundlag af det gennem denne undersøgelse oplyste slutte, at Bencdicht i lighed med Boltz har benyttet Steyners „Kunstbüchlin“ som kilde. Benedichts tekst er blevet optrykt af en ukendt bogtrykker, og denne tekst er ved udgivelsen af den danske Alessio-udgave optaget her. Da Boltz-oversættelsen gennem sin originaltekst kan henfores til Steyners „Kunstbüchlin“, vil det fremgå, at af de fire aldste danske illuminerbøger slutter de tre sig helt og den fjerde delvis til samme grundtekst. Denne grundtekst kan, på det i øjeblikket foreliggende grundlag, ikke spores langere tilbage end til Steyners bog. Når hensyn imidlertid tages til de ovenfor anførte ligheder mellem Strassburghåndskriftet, Liber illuministarium og Steyners bog, ligger det nær at antage, at disse tre receptbøger må have en fælles endnu ikke fremdraget håndskreven kilde.

1) Lauritz Nielsen: Boghistoriske Studier til dansk Bibliografi, 1923 p. 1oo. - 2) sst. p. 63. - 3) Krigsbogen findes udforligt omtalt i R. Paulli: Lorentz Benedicht, I920 p. XVII-XIX. - 4) sst. p. XIX. - 5) Sjallandske Tegnelser 26. Jan. og 8. Febr. ${ }_{5} 88$ (Kancelliets Brevboger). ${ }^{6}$ ) Brevene findes udforligt refereret i Paullis bog om Benedicht pp. XX-XXII. - 7) Kaanster (Benedicht) $\sim$ Konster (I633-trykket), schriffue (Ben.) $\sim$ scriffue (1633-tr.), gantske (Ben.) $\sim$ ganske ( 1633 -tr.). $-{ }^{8}$ ) Bogerne udkom med selvstændige titelblade, hvorpå intet er anfort om, at de udgor dele af ,Oeconomia Nova“. På bagsiden af fallestitelbladet findes imidlertid en fortegnelse over seriens enkelte boger. - 9) De forste delte udgaver var ,Artzney-Buch“ Basel 1575 og ,KunstBuch" Basel ${ }_{\left.1577 .-1^{\circ}\right)}$ Jöcher: Allgemeines Gelehrten-Lexikon, I, Leipzig I 750, p. 263 sp. 2 (Alexius). - ${ }^{\text {I }}$ ) Supplikation des Sebastian Häslin, Kirchenakten G 13 Staatsarchiv, Basel. (Gengivet af Fritz Mohr i: Die Dramen des Valentin Boltz, Basel 1916 p. 6). - ") Det nedenfor navnte Strassburg-hăndskrifts anden del (recept nr. 16 ff.) indledes med ordene: „Dis lert mich Meister Andres von Colmar." Ifolge Bergers bog (se note 16) kan håndskriftet dateres til det ${ }_{5} 5$. århundrede. - 13) Boltz: Illuminierbuch herausgegeben, mit Einleitung und Register versehen von Benziger (Sammlung maltechnischer Schriften IV) München 1913 p. 31 ff. Fritz Mohr (se note I 1 ) p. 7 fojer yderligere to udgaver til de af Benziger opregnede. $-{ }^{14}$ ) p. $5^{8}$ betegnet 46 , p. $63-96$ betegnet $73^{-106 .}-{ }^{15}$ ) I oversigten er de fejlagtige sidetal korrigeret. $-{ }^{16}$ ) Ernst Berger : Beiträge zur Entwicklungsgeschichte der Maltechnik, III Folge. München I9I2, p. I6r-163. - i ) Hândskriftet, hvis signatur var Ms. A VI Nr. 19, opbevaredes i Strassburg Stadtbibliothek, hvor det under en brand i 1870 gik tilgrunde. En afskrift findes i National Gallery of Art i London. ${ }^{18}$ ) Cod. germ. 821 Staatsbibliothek München. Hảndskriftet er skrevet i Tegernsee i det 15 . ârhundrede. 